\title{
Chemical characterization of fresh and composted livestock manures
}

\author{
M. Irshad*1 ${ }^{*}$ A. E. Eneji², Z. Hussain ${ }^{3}$ and M. Ashraf ${ }^{4}$ \\ ${ }^{1}$ Department of Environmental Sciences, COMSATS Institute of Information Technology, (CIIT) Abbottabad, Pakistan ${ }^{2}$ Department \\ of Soil Science, University of Calabar, Nigeria ${ }^{3}$ Department of Development Studies, CIIT Abbottabad, Pakistan ${ }^{4}$ Department of Civil \\ Engineering, CIIT Abbottabad, Pakistan*Corresponding author: mirshad@ciit.net.pk
}

\begin{abstract}
Effect of composting on the extractability of plant nutrients in organic wastes is essential for their recycling in sustainable soil fertility management. Therefore, an experiment was carried out to determine the concentrations of total C, total N, extractable P, K, Na and B in five types of fresh and composted manures (namely buffalo, camel, cow, goat and poultry). Laboratory results showed that the extractability of elements varied considerably with the type of composted manure. Total $\mathrm{C}$ varied in the order cow $>$ goat $>$ buffalo $>$ poultry $>$ camel while total $\mathrm{N}$ was in the order buffalo $>$ poultry $>$ cow $>$ camel $>$ goat. Total C, total N, extractable $\mathrm{K}$ and Na decreased with composting, whereas extractable $\mathrm{P}$ and $\mathrm{B}$ increased. Goat manure had higher $\mathrm{pH}$ and $\mathrm{EC}$ values than cow and poultry manures whether in fresh or composted samples. A marked increase in the EC value was observed in composted manures, whereas $\mathrm{pH}$ was reduced with composting.
\end{abstract}

Keywords: Chemical characterization; composted manure; fresh manure

\section{Introduction}

Continued disposal of large amounts of raw manure may result in soil and water contamination via leaching of toxic elements, nutrient imbalances and phytotoxicity in crops (Milan and Fernandes, 1996). Composting has become a preferred method for a variety of processing organic byproducts for application as soil conditioners and amendments (Butler et al., 2001). One of the most important advantages of using composted manure for agricultural purposes is its stability and maturity Application of undecomposed wastes or non-stabilized compost to land may lead to immobilization of plant nutrients and cause phytotoxicity due to insufficient biodegradation of organic matter (Butler et al., 2001). Hue and Liu (1995) also associated the application of immature compost with the release of phytotoxic compounds during composting. Composted manure is preferred because of its reduced volume and ease of handling due to smaller particle size that facilitates more uniform application (Eneji et al., 2001; Larney and Blackshaw, 2003; Richard and Choi, 1999).

The introduction of appropriate management technologies could mitigate the health and environmental risks associated with the over production 
of organic wastes derived from the livestock industry by stabilizing them before their use or disposal. The management of livestock manures with consideration for environmental quality should be an important goal when recycling farm wastes as soil amendments (Eneji et al., 2003a; Bolan et al., 2004).

Composted materials have gained a wide acceptance as organic amendments for sustainable agriculture, as they have been shown to increase soil organic matter levels, improve soil physical properties and modify soil microbial communities, thereby enhancing microbial biomass, activity and diversity. Composting is considered as a viable and environmentally sound method of waste management that hastens the decomposition of the organic waste under controlled conditions, thereby reducing its volume (Eneji et al., 2001). The final product of this process is a stable, phytotoxicity-free and enriching-humus material known as compost, which is characterized by a high content of available-plant nutrients such as nitrogen, phosphorus, potassium, calcium and magnesium (Eneji et al., 2001). It is a microbial driven process, during which microorganisms utilize the decomposable organic waste both as a source of food and energy (Chefetz et al., 1998).

It is of great importance to provide further information regarding the nutritional and toxicity status of manure amendments, as a wide range of physico-chemical and biochemical changes do occur during composting. For instance, Eneji et al. (2001) found an increase in humic acid and acid-extractable phosphorus along with a decline in the levels of carbon and nitrogen. Since the total concentration of elements in manures may not provide the best indication of their bioavailability, evaluating the effects of composting on the extractable forms of elements in wastes is essential for the sustainable nutrient management of crops. Eneji et al. (2001) reported the physico-chemical changes during aerobic composting. The nutrient loss through runoff is related to the eutrophication of water bodies and it can become a major problem, especially in areas with an intensive animal husbandry. Therefore, the characterization of farm wastes compost should enable us to predict the behavior and fate of elements when compost is used as a soil amendment and also to identify sustainable field management practices to reduce possible nutrients losses.

Several studies have been conducted on the release of major constituents from manures during composting. However, research into the extractability of nutrient elements from fresh and composted manures of different livestock have been insufficiently reported. Therefore, an experiment was carried out to compare the concentrations of total $\mathrm{C}$, total $\mathrm{N}$, extractable $\mathrm{P}, \mathrm{K}$, $\mathrm{Na}$ and $\mathrm{B}$ in fresh and composted manures from five animal sources (i. e., buffalo, camel, cow, goat and poultry manure).

\section{Materials and Methods}

The different sources of manure (buffalo, camel, cow, goat and poultry manure) were collected from various locations in the district Abbottabad and composted for 112 days (16 weeks) under room temperature during summer in loosely folded black plastic bags. The manure samples were replicated thrice. Moisture in the manure was maintained at $20 \%$ and occasionally samples were turned at weekly intervals and mixed. Additional water was added as required. The compost temperature was measured daily at 1500 hours until it equaled that of the ambient. After composting, the manure samples were thoroughly mixed. The samples were dried $\left(60{ }^{\circ} \mathrm{C}\right)$, ground, and screened via a 0.5 $\mathrm{mm}$ sieve for various analyses. For the determination of water extractable nutrients, $10 \mathrm{~g}$ manure samples were added $100 \mathrm{~mL}$ of distilled water and the samples were shaken on a mechanical shaker and thereafter filtered. Total carbon content was determined by dry- combustion using the method proposed by Nelson and Sommers (1982). Total nitrogen content was determined following the method of Winkleman et al. (1984). Phosphorus (P) was measured with a spectrophotometer according to the phosphomolybdate 
blue method (Olsen and Sommers, 1982). Potassium (K) was measured with a flame photometer (Soltanpur and Workman, 1979). Boron (B) was determined with a spectrophotometer at $420 \mathrm{~nm}$ following the method of Rashid et al. (1994). The $\mathrm{pH}$ of manure suspension with manure:water ratio of 1:10 was determined using a $\mathrm{pH}$ meter (Model: HANNA HI 8520). Electrical conductivity (EC) in the manure suspension was measured by an electrical conductivity meter (Model: 4320 JENWAY). Data were statistically analyzed using Statview software (SAS, 1999) and results were expressed on oven-dry basis. Mean separation was done using LSD at $p<0.05$.

\section{Results and Discussion}

Extractability of elements differed significantly $(p<0.05)$ between fresh and composted manure irrespective of the kind of animal manure. The differences in nutrient concentrations were highly related to the type of manure composted (Figure 1-3). For total $\mathrm{C}$ content, manures differed in the order cow $>$ goat $>$ buffalo $>$ poultry $>$ camel. There was an obvious reduction in total $\mathrm{C}$ in composted manures as compared to fresh manures. The reductions in total C was $15 \%$ for buffalo, $21 \%$ for camel, $17 \%$ for cow, $32 \%$ for goat and $29 \%$ for poultry manure. Generally, the source of raw material influences the humification process during composting (Chefetz et al., 1996). This is not unexpected since composting is essentially a biochemical process in which $\mathrm{C}$ and $\mathrm{N}$ are mineralized and lost in gaseous forms as carbon dioxide, ammonia, $\mathrm{N}_{2} \mathrm{O}$ and $\mathrm{N}_{2}$. These declining trends were similar to those reported previously (Eneji et al., 2003a). Eneji et al. (2003b) also reported a decrease in total $\mathrm{C}$ by $18 \%$ after 195 days of co-composting animal wastes. It has been reported elsewhere that chemical composition affected the decomposition rate of all organic matter including crop residues (Kumar and Goh, 2000; Martens, 2000), compost (Tiquia et al., 2002), and manure (Gordillo and Cabrera, 1997).

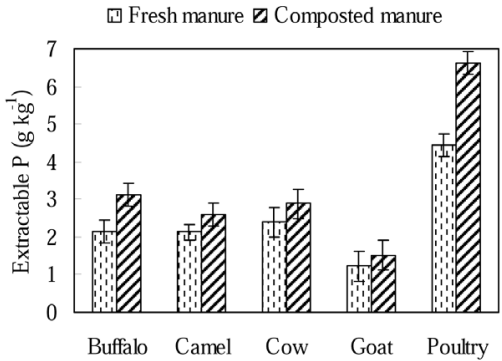

Figure 1. Changes in total $\mathrm{C}$ and total $\mathrm{N}$ in fresh and composted livestock manures
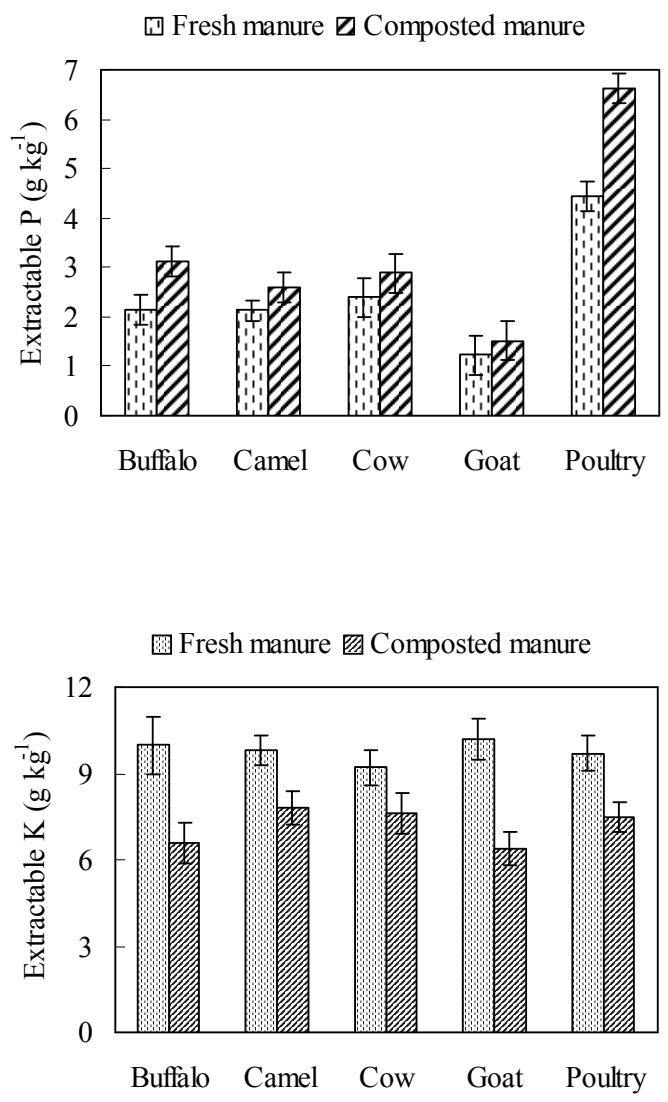

Figure 2. Changes in extractable $\mathrm{P}$ and $\mathrm{K}$ in fresh and composted livestock manures 
Our fresh (non-composted) manures had much higher total $\mathrm{N}$ content than composted manures (Figure 1) and among sources, total $\mathrm{N}$ varied in the order buffalo $>$ poultry $>$ cow $>$ camel $>$ goat. Since the content of $\mathrm{N}$ declined significantly with composting, it would be necessary to supplement the manure with inorganic sources of $\mathrm{N}$ when applied as fertilizer. The lower total $\mathrm{N}$ in composted samples may also infer that the use of composted waste would be less polluting. Irshad et al. (2011) reported a marked decrease in extractable $\mathrm{NH}_{4}-\mathrm{N}$ during composting. Fresh manure had $87 \mathrm{mg}$ $\mathrm{kg}^{-1}$ of $\mathrm{NH}_{4}$ compared with only $15 \mathrm{mg} \mathrm{kg}^{-1}$ after 100 days of composting.

Significant increases in extractable $\mathrm{P}$ were found in composted manure as compared to fresh manure (Figure 2). The content in fresh manures were in the order poultry $>$ cow $>$ buffalo $>$ camel $>$ goat, whereas in composted the pattern was poultry $>$ camel $>$ cow $>$ buffalo $>$ goat. The extractable $\mathrm{P}$ increased when composted by $44 \%$ in buffalo, $22 \%$ in camel, $21 \%$ in cow, $24 \%$ in goat and $49 \%$ in poultry manure (Figure 2). The fluctuation observed in the release of $\mathrm{P}$ nutrient could be due to the variation in the microbial activity, $\mathrm{C} / \mathrm{N}$ ratio of manure samples and time of composting. Adler and Sikora (2005) observed an increased inorganic $\mathrm{N}$ and decreased water-extractable $\mathrm{P}$ as the organic matter decomposed. Others have also observed a decrease in water-extractable P over time with different types of composts (Traore et al., 1999). When $\mathrm{P}$ was fractionated, it was found that forms of inorganic $\mathrm{P}$ such as $\mathrm{HCl}$-soluble $\mathrm{P}$ increased and waterextractable P decreased (Traore et al., 1999; Eneji et al., 2003c) over time of composting. This trend suggests the possible transformation of water-extractable $\mathrm{P}$ to more stable forms, which would reduce the potential for runoff losses.

Statistically significant $(p<0.05)$ changes were found for $\mathrm{K}$ content among livestock manures butthe content substantially decreased after composting (Figure 2). Fresh manure $\mathrm{K}$ levels $\left(\mathrm{g} \mathrm{kg}^{-1}\right)$ were in the order of 10.1 for buffalo, 9.8 for camel, 9.2 for cow, 10.2 for goat and 9.7 for poultry manure.
After composting the values $\left(\mathrm{g} \mathrm{kg}^{-1}\right)$ were $6.6,7.8$, 7.6, 6.4 and 7.5 respectively. The decreased $\mathrm{K}$ in composted samples could be attributed to the formation of insoluble $\mathrm{K}$ complexes in the presence of inorganic elements or changed $\mathrm{pH}$ value. Viller et al. (1993) reported differences of 42 and 55\% in the contents of available $\mathrm{Ca}$ and $\mathrm{Mg}$ extracted with acetic acid after composting of the manure. Eneji et al. (2003c) reported that manure was an ample source of macro- and micronutrients upon application to soils. Chemical composition of manure can influence the amount of nutrients released, and the rate at which they are released. Significant correlations have been reported between the initial chemical composition of organic residues and the mineralization rate (Palm and Sanchez, 1991; Mafongoya et al., 1997).

A marked decrease in the extractable $\mathrm{Na}$ was observed after composting. Fresh buffalo manure exhibited the highest concentration of $\mathrm{Na}$ followed by poultry and camel manures whereas goat and cow showed relatively lower concentration. The low extractability of $\mathrm{Na}$ in composted samples may suggest that the use of composted animal waste would be beneficial to sodic soils. All manure samples showed a similar pattern of nutrient release in the order of $\mathrm{K}>\mathrm{Na}>$ $\mathrm{P}>\mathrm{B}$. Unlike $\mathrm{Na}, \mathrm{B}$ concentrations were greater in composted than fresh manures by $64 \%$ higher in buffalo, $6 \%$ in camel, $7 \%$ in cow, $13 \%$ in goat and $6 \%$ in poultry manure. Boron levels in manures were in the order cow $>$ goat $>$ camel $>$ poultry $>$ buffalo. Bolan et al. (2004) reported that the concentration of trace elements can vary considerably among animal manures. Additional variation is associated with the age of the animal, type of ration, housing type, and waste management practice. Eneji et al. (2003a) reported marked increases in total $\mathrm{Fe}, \mathrm{Zn}, \mathrm{Cu}$ and $\mathrm{Mn}$, especially under anaerobic conditions during composting and decreases in the available heavy metal contents. Increased use of trace elements in animal feed have often concentrated their levels in manure by-products. The type of bedding material in animal wastes may also influence the litter dry 
The electrical conductivity (EC) of manures increased substantially with composting, especially for buffalo, cow and poultry manure (Figure 4). This may be related to the transformation of organic material into inorganic forms. The EC level increased after composting from 8.6 to 9.5 in buffalo manure, 8.7 to 9 in camel manure, 9.6 to 10.7 in cow manure, 10.3 to 10.6 in goat manure and 8.3 to 9.2 in poultry manure. The higher EC values in composted manures could be attributed to the release of salts from the manure with the passage of time. Chang et al. (1990) found that manure application increased the total soluble salts and $\mathrm{Na}$ adsorption ratio in the soil. Changes in $\mathrm{EC}$ of certain composts could also be used as an index of compost maturity. Whenever the EC (together with nitrate and soluble organic matter) of cattle manure compost exhibited a constant value, the material was judged to be mature enough to be used as organic compost in container media (Inbar et al., 1991). Electrical conductivity is a measure of total cations and anions in solution and was usually determined largely by $\mathrm{Mg}$ and $\mathrm{Ca}$ ions (Clark et al., 1998).

Manure $\mathrm{pH}$ (except for poultry manure) reduced significantly with composting (Figure 4). The $\mathrm{pH}$ of buffalo manure was 8.7 in fresh and reduced to 7.7 in composted sample. For camel manure, the $\mathrm{pH}$ was 8.6 in fresh and 8.5 in compost, for cow manure $\mathrm{pH}$ was 8.5 in fresh and 7.4 in manure compost. Goat fresh manure showed $\mathrm{pH}$ of 8.9 and 7.8 in composted manure. Poultry manure had a $\mathrm{pH}$ of 8 in fresh and 8.4 in compost. This decrease in $\mathrm{pH}$ could be attributed to the modified chemical composition of manure through microbial action, notably the production of organic acids.
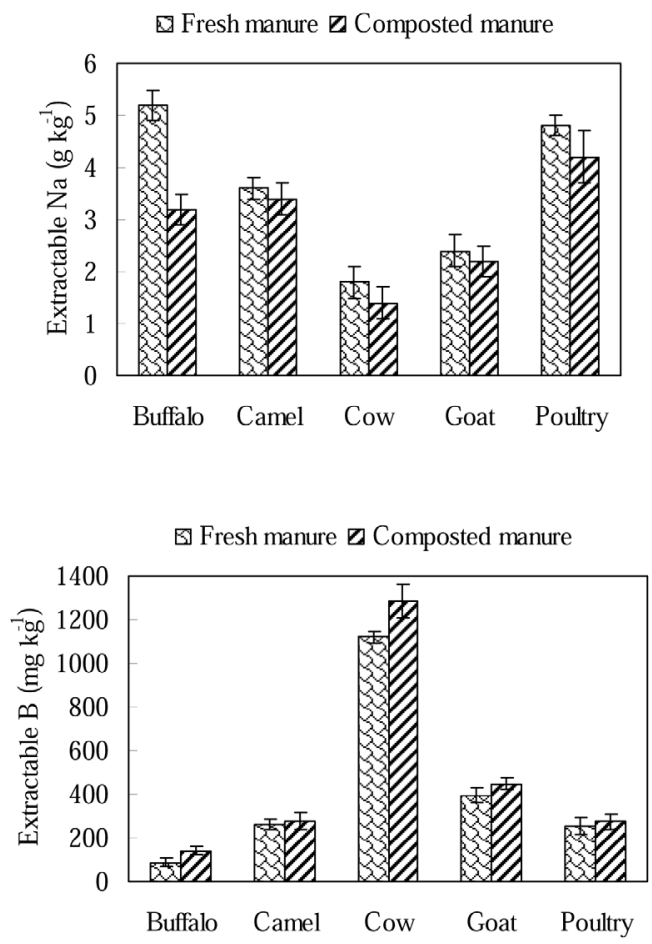

Figure 3. Changes in extractable $\mathrm{Na}$ and $\mathrm{B}$ in fresh and composted livestock manures

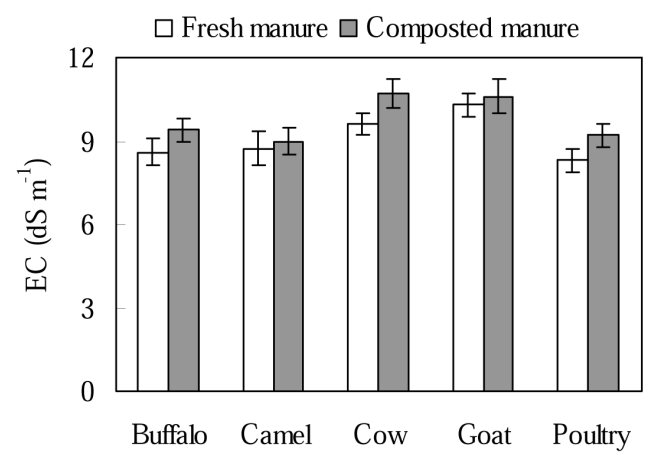

Figure 4. Changes in $\mathrm{pH}$ and $\mathrm{EC}$ in fresh and composted livestock manures 


\section{Conclusions}

There were considerable differences in elemental composition among manures from different animal sources and composting reduced the contents of total $\mathrm{C}$ and $\mathrm{N}$, exchangeable $\mathrm{K}$ and $\mathrm{Na}$ and $\mathrm{pH}$ but increased the EC, extractable $\mathrm{P}$ and $\mathrm{B}$. These changes reflect a stabilization of the manure. Thus for use as soil amendments, the composted manure may need supplementation with inorganic $\mathrm{N}$ and $\mathrm{K}$, depending on soil test results and crop requirements.

\section{References}

Adler, P.R., Sikora, L.J. 2004. Composting Fish Manure from Aquaculture Operations. BioCycle. 45, 62-66.

Bolan, N.S., Adriano D.C., Mahimairaja, S. 2004. Distribution and bioavailability of trace elements in livestock and poultry manure by-products. Crit. Rev. Environ. Sci. Tech. 34, 291-338.

Butler, T.A., Sikora, LJ., Teeinhilber, P.M., Douglass, L.W. 2001. Compost age and sample storage effects on maturity indicators of biosolids compost. J. Environ. Qual. 30, 2141-2148.

Chang, C., Sommerfeldt, T.G., Entz, T. 1990. Rates of Soil Chemical Changes with Eleven Annual Applications of Cattle Feedlot Manure. Canad. J. Soil Sci. 70. 673-681.

Chefetz, B., Adani, F., Genevini, P., Tambone, F., Hadar, Y., Chen, Y. 1998. Humic-acid transformation during composting of municipal solid waste. J. Environ. Qual. 27, 794-800.

Clark, M.S., Horwath, W.R., Shennan, C., Scow, K.M. 1998. Changes in soil chemical properties resulting from organic and low-input farming practices. Agron. J. 90, 662-671.
Eneji, A. E., Yamamoto, S., Honna, T., Ishiguro, A. 2001. Physicochemical changes in livestock feces during composting, Commun. Soil Sci. Plant Anal. 32 (3-4), 477-489.

Eneji, A. E., Honna, T., Yamamoto, S., Masuda, T., Endo, T., Irshad, M. 2003a. The Relationship between total and available heavy metals in composted manure. J. Sust. Agric. 23,1, 125-134.

Eneji, A.E., Honna, T., Yamamoto, S., Masuda, T., Irshad, M. 2003b. Changes in humic substances and phosphorus fractions during composting. Commun. Soil Sci. Plant Anal. 34 ,15 - 16, 23032314.

Eneji, A.E., Irshad, M., Honna, T., Yamamoto, S., Endo, T., Masuda, T. 2003c. Potassium, calcium and magnesium mineralization in manure treated soils. Commun. Soil Sci. Plant Anal. 34,11 -12, 1669-1679.

Gordillo, R.M., Cabrera, M.L. 1997. Mineralizable nitrogen in broiler litter. I. Effect of selected litter chemical characteristics. J. Environ. Qual. 26, 1672-1679.

Hue, N.V., Liu, J. 1995. Predicting compost stability. Compost Sci. Util. 3, 8-15.

Inbar, Y., Chen, Y., Hadar, Y. 1991. Carbon-13 CPMAS and FTIR Spectroscopic Analysis of organic matter transformation during composting of solid wastes from wineries. Soil Sci. 152, 272-282.

Irshad, M., Inoue, M., Shezadi, M., Tariq, M., Faridullah. 2011. Investigating ammonium, phosphorus and potassium release from animal manure during composting. J. Food Agric. Environ. 9, 2, 629-631.

Kumar, K., Goh, K.M. 2000. Crop Residue and Management Practices: effects on soil quality, soil nitrogen dynamics, crop yield, and nitrogen recovery. Adv. Agron. 68, 197-319. 
Larney, F.J., Blackshaw, R.E. 2003. Weed seed viability in composted beef cattle feedlot manure. J. Environ. Qual. 32, 1105-1113.

Mafongoya, P L., Dzowela, B.H., Nair, P.K. 1997. Effect of multipurpose trees, age of cutting and drying method on pruning quality. In Cadisch, G.; Giller, K. E. Eds. Driven by Nature: Plant Litter Quality and Decomposition. CAB International, Wallinford, U. K. 167-174.

Martens, D.A. 2000. Plant Residue Biochemistry Regulates Soil Carbon Cycling and Carbon Sequestration. Soil Biol. Biochem. 32, 361-369.

Milan Ihnat, A., L. Fernandes. 1996. Trace elemental characterization of composted poultry manure. Biores. Tech. 57, 143-156.

Nelson, D.W., Sommers, L.E. 1982. Organic carbon. In: Methods of Soil Analysis, Part 2, ASA, SSSA, Madison, WI, USA, pp. 561-579.

Olsen, S.R., Sommers, L.E. 1982. Phosphorus. In: Methods of Soil Analysis, Part 2 (2nd ed.), ASA, SSSA, Madison, WI, USA (1982), pp. 406-407.

Palm, C.A., Sanchez, P.A. 1991. Nitrogen Release from the Leaves of Some Tropical legumes as affected by their lignin and polphenolic contents. Soil Biol. Biochem. 23, 83-88.

Rashid, A., Rafique, E., Bughio, N. 1994. Diagnosing boron deficiency in rapeseed and mustard by plant analysis and soil testing. Commun. Soil Sci. Plant Anal. 25, 2883-2897.
Richard, T.L., Choi, H.L. 1999. Eliminating waste: Strategies for sustainable manure management. Asian-Austr. J. Animal Sci. 12, 1162-1169.

SAS. 1999. Stat View Reference. third ed.. SAS Institute Inc., Cary, NY, USA.

Shiralipour, A. 1992. Physical and chemical properties of soils as affected by municipal solid waste compost application. Biomass Bioenergy, 3, 261266.

Soltanpur, P.N., Workman, S. 1979. Modification of the NH4HCO3-DTPA soil test to omit carbon black. Commun. Soil Sci. Plant Anal. 10, 14111420

Traore, O., Sinaj, S., Frossard, E., Van De Kerkhove, J.M. 1999. Effect of composting time on phosphate availability. Nutr. Cycl. Agroecosys. $55,123-131$.

Tiquia, S.M., Richard, T.L., Honeyman, M.S. 2002. Carbon, nutrient, and mass loss during composting. Nutr. Cycl. Agroecosys. 62, 15-24.

Villar, M.C., Beloso, M.C., Acea, M.J., Cabaneiro, A., Gonzles-Prieto, S.J. 1993. Physical and chemical characterization of four composted urban refuses. Biores. Tech. 45, 105-113.

Winkleman, G.E., Mcleod, J.G., McAndrew, D.W. 1984. Chemical methods of soil, plant, water and blood analysis. Agriculture Canada, Swift Current, Saskatchewan, Canada. 